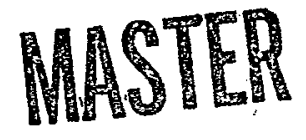

\title{
MICROSTRUCTURAL STABILITY OF
}

\section{1-6-9 STAINLESS STEEL}

Robert $\boldsymbol{W}$. Krenzer

Elane C. Sanderson

Materials Technology GENERAL METALLURGY

\section{Rockwell International \\ Atomica International Division Rocky Flats Plant$$
\text { P.O. Box } 464
$$ \\ Golden, Colorado 80401}

U. S. DEPARTMENT OF ENERGY CONTRACT EY -76-C - $04-3533$ 


\section{DISCLAIMER}

This report was prepared as an account of work sponsored by an agency of the United States Government. Neither the United States Government nor any agency Thereof, nor any of their employees, makes any warranty, express or implied, or assumes any legal liability or responsibility for the accuracy, completeness, or usefulness of any information, apparatus, product, or process disclosed, or represents that its use would not infringe privately owned rights. Reference herein to any specific commercial product, process, or service by trade name, trademark, manufacturer, or otherwise does not necessarily constitute or imply its endorsement, recommendation, or favoring by the United States Government or any agency thereof. The views and opinions of authors expressed herein do not necessarily state or reflect those of the United States Government or any agency thereof. 


\section{DISCLAIMER}

Portions of this document may be illegible in electronic image products. Images are produced from the best available original document. 
Printed

Máy 18, 1978
RFP-2668

UC-25 MATERIALS

TID-4500-R66

\title{
MICROSTRUCTURAL STABILITY OF
}

\section{1-6-9 STAINLESS STEEL}

Robert W. Krenzer

Elane C. Sanderson

Materials Technology

GENERAL METALLURGY

\begin{abstract}
This report was prepared as an account of work sponsored by the United States Govemment. Neither the United States nor the United States Department of Energy, nor any of their employees, nor any of their contractors, subcontractors, or their employees, makes any warranty, express or implied, or assumes any legal liability or responsibility for the accuracy, comple teness or usefulness of any information, apparatus, product or process disclosed, or represents that its use would not infringe privately owned rights.
\end{abstract}

ROCKWELL INTERNATIONAL ATOMICS INTERNATIONAL DIVISION ROCKY FLATS PLANT

P. O. BOX 464

GOLDEN, COLORADO 80401

Propared under Contract EY-76-C-04-3533 for the

Albuquerque Operations Office U.S. Department of Energy 
RFP-2668

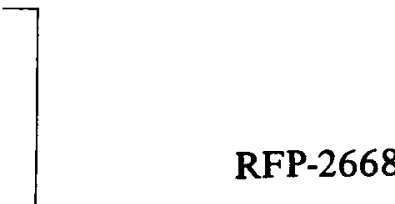

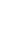




\title{
CON T E N T S
}

\begin{abstract}
$\ldots \ldots \ldots \ldots \ldots \ldots \ldots \ldots \ldots \ldots \ldots \ldots \ldots \ldots$
Introduction $\ldots \ldots \ldots \ldots \ldots \ldots \ldots \ldots \ldots \ldots \ldots \ldots \ldots \ldots \ldots$

Experimental Procedure $\ldots \ldots \ldots \ldots \ldots \ldots \ldots \ldots \ldots$

Results and Discussion $\ldots \ldots \ldots \ldots \ldots \ldots \ldots \ldots \ldots$

Microstructure $\ldots \ldots \ldots \ldots \ldots \ldots \ldots \ldots \ldots \ldots$

Mechanical Properties ..................4 4

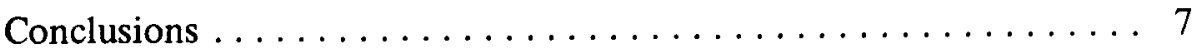

References $\ldots \ldots \ldots \ldots \ldots \ldots \ldots \ldots \ldots \ldots \ldots \ldots$
\end{abstract}


RFP-2668 


\title{
MICROSTRUCTURAL STABILITY OF
}

\author{
21-6-9 STAINLESS STEEL
}

\author{
Robert W. Krenzer and Elane C. Sanderson
}

\begin{abstract}
Two experiments were designed to better define parameters for thermomechanical processing of 21-6-9 stainless steel. This steel is one of the nitrogen-strengthened chromium, manganese, and nickel austenitic stainless steels having mechanical properties that can be improved by a combination of plastic deformation and heat treatments. By heat-treating coupons, the time-temperature relationship of the precipitate phase, and the solutionizing, recrystallizing, and stress-relieving temperature ranges in 21-6-9 were established. Secondly, mechanical properties and microstructure as a function of percent deformation and stess-relieving temperature are reported.
\end{abstract}

\section{INTRODUCTION}

Thermomechanical processing (TMP) has long been recognized as an effective means of achieving improved mechanical properties in many metals and alloy systems. Austenitic stainless steels respond well to TMP, and desirable combinations of strength and ductility can be achieved by warm and cold working. Improved strengths by induced deformation can have its disadvantages, however. Several investigators have observed that cold-work accelerates the formation of undesirable phases. ${ }^{1-3}$ Second phases are undesirable because they are known to produce adverse effects on properties. such as fracture toughness, hydrogen compatibility, corrosion resistance, and mechanical properties. Unfortunately, in many cases, inadequate attention is paid to the possible introduction of second phases into an alloy as a result of improper processing parameters.

Process control is important in critical applications. In the case of 21-6-9, little is known about the effect of thermal and mechanical treatments on the microstructural stability of the steel. The significance of precipitation of unidentified phases on various physical and mechanical properties also is unknown.
TABLE 1. Composition of 21-6-9 Used to Determine the Effect of Time, Temperature, and Percent Cold Work on Mechanical Properties of Thermomechanically Processed 21-6-9 Stainless Steel

\begin{tabular}{lccc}
\multicolumn{2}{c}{ Heat No. 4568-2 } & Heat No. 91523 \\
\hline Carbon (\%) & -0.028 & 0.014 \\
Sulfur (\%) & -0.002 & 0.006 \\
Nitrogen (\%) & -0.29 & 0.24 \\
Oxygen (ppm) & -26 & - \\
Chromium (\%) & -19.4 & 19.8 \\
Manganese (\%) & -9.53 & 9.21 \\
Nickel (\%) & -6.78 & 7.10 \\
Phosphorus (\%) & $-<0.02$ & 0.011 \\
Silicon (\%) & -0.26 & 0.15 \\
Aluminum (ppm) & -150 & 170 \\
Iron & - balance & balance \\
\hline
\end{tabular}

There is concern that enhanced precipitation due to cold work will contribute to a degradation of part properties. The present work therefore is concerned with time-temperature relationships for the formation of precipitates in deformed 21-6-9 stainless steel. From this, a better understanding of how to avoid precipitation during TMP of the steel can be derived.

\section{EXPERIMENTAL PROCEDURE}

In the present work, samples from two experiments were investigated. Compositions of the two heats of 21-6-9 studied are given in Table 1 .

Material from Heat Number 4568-2 was used to cold-form hemishells by means of the TMP outlined in Table 2. Thin strips were machined from the equator of the hemishell and were cut into coupons $0.64 \times 0.32 \times 1.27 \mathrm{~cm}$. These samples were taken from the hemishell region that received the maximum amount of deformation. Worked samples were then reheated to several temperatures 
TABLE 2. Thermomechanical Process for Forming Hemishell from Heat 4568-2

1. Solutionize plate $\left(1.75 \mathrm{in}\right.$.) for 2 hours at $1065^{\circ} \mathrm{C}$.

2. Hot roll from $1065^{\circ} \mathrm{C} \quad 1.75$ in. $\rightarrow 0.25$ in.

3. Intermediate solution anneal for 1 hour at $1065^{\circ} \mathrm{C}$.

4. Cross cold-roll plate to final thickness 0.25 in. $\rightarrow 0.20$ in.

5. Cut disc, marform hemishell.

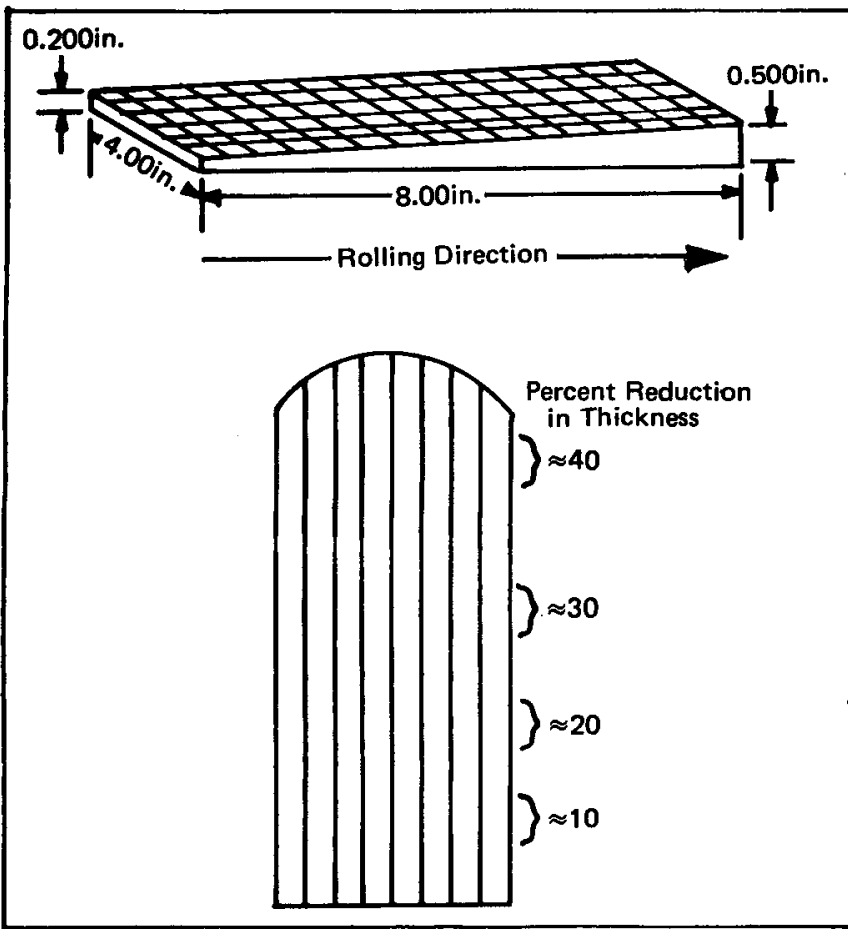

FIGURE 1. Wedge from 21-6-9 Vaçuum Induction Melt-Electroslag Remelt Billet

between 482 and $1094{ }^{\circ} \mathrm{C}$ for various lengths of time. Formed parts are typically stress relieved at temperatures within this range. These heat treatments were done to optically observe microstructural changes that occur in deformed material. Aging treatments were done in a tube furnace under an argon atmosphere.

A second experiment involved $1.55-\mathrm{cm}$ plate stock from Heat Number 91523. The plate, which was produced from a VIM/ESR, ${ }^{*} 22.86-\mathrm{cm}, \mathrm{RCS} \dagger$ billet, was first solutionized at $1094^{\circ} \mathrm{C}$ for five hours. It was then alternately cross-rolled at

*VIM - Vacuum induction melted; ESR - Electroslag remelt $\dagger$ RCS - Round cornered square

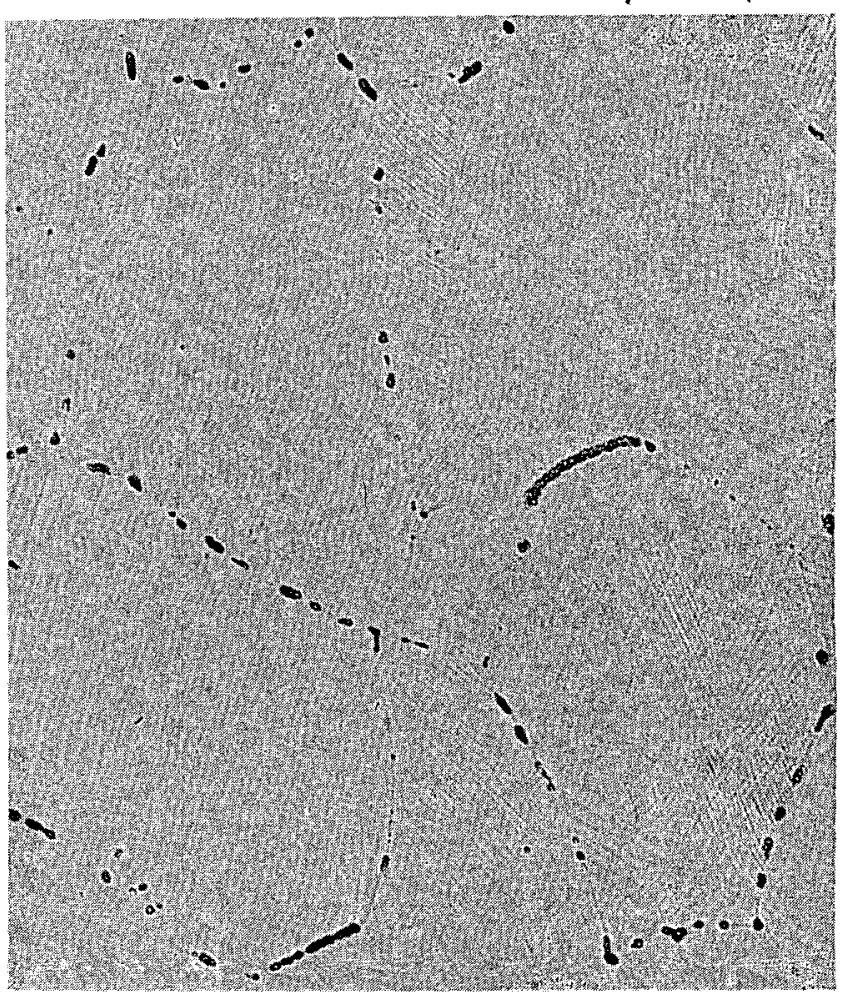

FIGURE 2. Microstructure of Hemishell Before Heat Treatment. (KCN Etch, 400X)

$1094{ }^{\circ} \mathrm{C}$ from 13.23 to $1.55 \mathrm{~cm}$ and finally was air cooled. Next, a wedge was machined from the plate stock. The wedge, having the dimensions shown in Figure 1, was resolutionized for one hour at $1094{ }^{\circ} \mathrm{C}$ and water quenched. It was then rolled at room temperature until there was a deformation gradient of about $0-45 \%$ reduction in thickness.

Prior to being rolled, the wedge was scribed with a $1.27-\mathrm{cm}$ grid. At the intersecting points of that grid, a micrometer was used for thickness measurements before and after rolling.

Four strips were cut from the wedge, three of which were reheated to 480,590 , and $670^{\circ} \mathrm{C}$ for one hour, and microtensile bars were machined from each strip. This provided a matrix of samples to determine tensile properties and metallography as a function of the degree of deformation and the reheat temperature.

A determination was sought regarding temperature ranges where precipitation can occur in 21-6-9. To accomplish this, numerous coupons were machined from formed hemishells. 


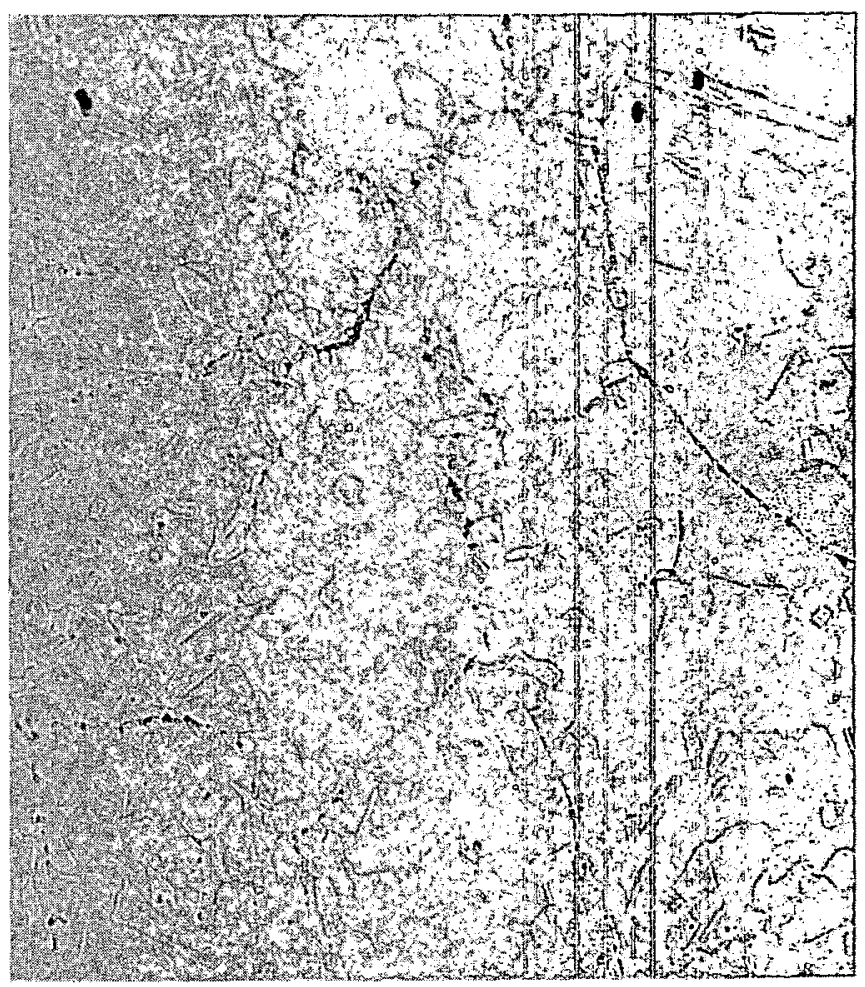

FIGURE 3. Microstructure of Hemishell, with One-Hour Stress Relieve at $700{ }^{\circ} \mathrm{C}$, Showing Extensive Precipitation. (KCN Etch, 400X)

The coupons were then heat-treated at intervals of about $20^{\circ} \mathrm{C}$ in a temperature range of 480 to $1094{ }^{\circ} \mathrm{C}$. Duration of each step varied up to 120 minutes. This report discusses samples heat-treated for one hour at the various temperatures. It is estimated that the coupons contained about $40 \%$ cold work prior to heat treatment. Figure 2 shows the microstructure prior to heat treatment.

Several etchants were used in searching for the one that best reveals precipitation in 21-6-9. It was found that the most effective procedure for mounted samples is as follows:

1. Remove rough surface by using, in ascending order, 60-, 180-, 320-, 400-, and 600-grit paper.

2. Polish on syntron using silk cloth from 15 - to 6- to 3- to 1-micron silk cloth.

3. Final hand polish using 0.05 -micron alumina.

4. Electrolytically etch using $10 \%$ potassium cyanide ( 0.8 amps, 5 volts for 6 minutes).

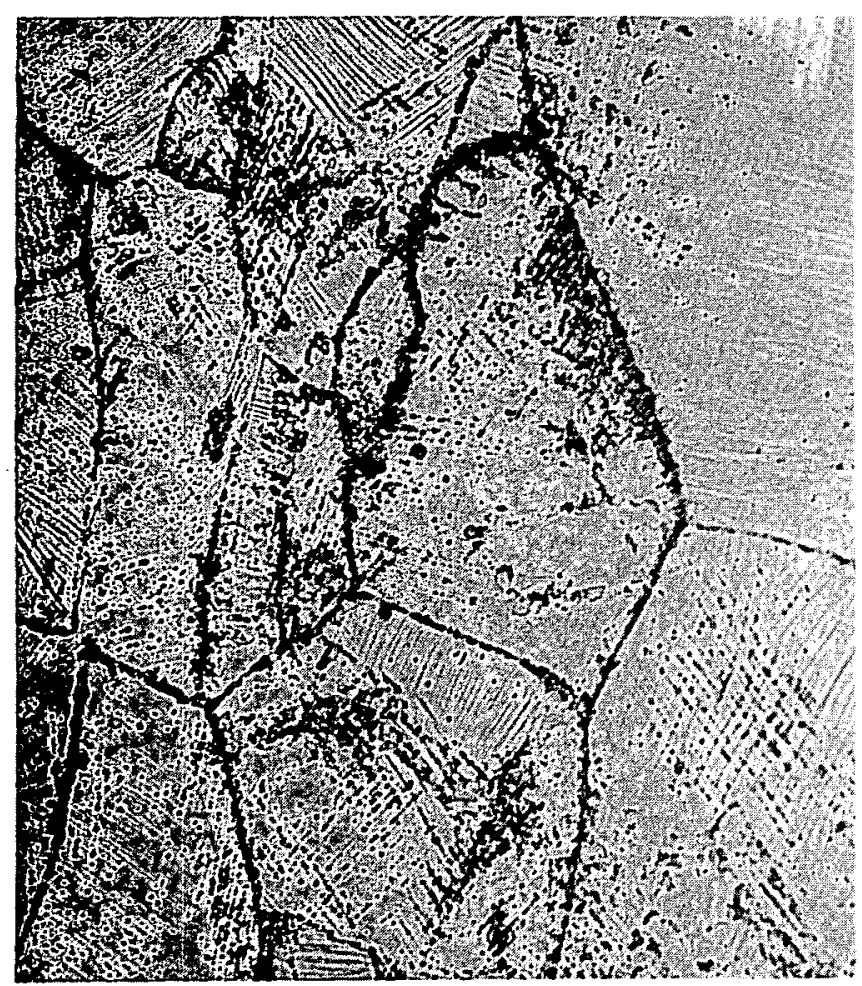

FIGURE 4. Microstructure of Hemishell, with One-Hour Stress Relieve at $788^{\circ} \mathrm{C}$, Showing Recrystallization and Precipitates Outlining Prior Austenitic Grain Boundaries. (KCN Etch, 400X)

All of the photomicrographs in this report were obtained using the above procedure.

\section{RESULTS AND DISCUSSION}

\section{Microstructure}

It is believed that numerous precipitates within the grain boundaries were formed during rolling and are still present because of inadequate solution treatment at $1065^{\circ} \mathrm{C}$. Solution treatment at $1094{ }^{\circ} \mathrm{C}$ completely dissolves these grain boundary precipitates after one hour at temperature. Precipitates did not form on deformation bands within the grains; however, at about $600^{\circ} \mathrm{C}$, deformation bands and slip lines within the grains begin to be outlined with a fine precipitate, as shown in Figure 3. These bands and lines become heavy at about $700{ }^{\circ} \mathrm{C}$. Above $775^{\circ} \mathrm{C}$, the material recrystallizes, which is a change associated with dissolution of fine precipitate within the grains. The change results in precipitates being left that outline prior grain boundaries (see Figure 4). This 


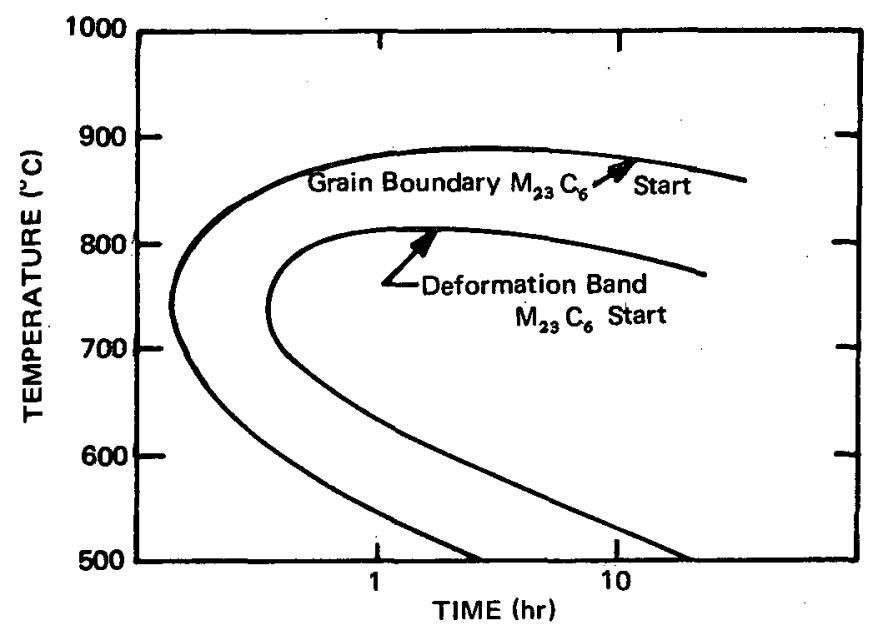

FIGURE 5. "C" Curve Behavior of $\mathrm{M}_{23} \mathrm{C}_{6}$ Precipitate in 21-6-9 Stainless Steel

second phase in the grain boundaries is still present after one hour at $900^{\circ} \mathrm{C}$. Above $900^{\circ} \mathrm{C}$, rapid grain growth occurs.

From the results of this study, rough C-curves for worked material are as sketched in Figure 5. The two separate stability regions indicate that there is a lower temperature phase that forms on deformation bands. The separate regions also suggest a higher temperature phase that precipitates in grain boundaries. It is possible that the precipitate is the same phase and nucleates at different sites within the two temperature ranges described. The complete extent of the stability range for the precipitate has not been fully investigated.

Identification of the precipitates also has not been fully investigated although efforts currently are underway. Their stability, as a function of alloy chemistry and degree of deformation, is also of interest. The lower temperature phase correlates well with observed sensitization behavior of stainless steels. This correlation is due to the formation of a carbide phase. Transmission electron microscopy (TEM) studies have identified some of the precipitates as $\mathrm{M}_{23} \mathrm{C}_{6}$.

Precipitation observed in this study is similar to the microstructures of actual forgings. The photomicrograph in Figure 6 is typical of high-energy rate forged 21-6-9 that has been forged above $760^{\circ} \mathrm{C}$. Heavy precipitation within the grain

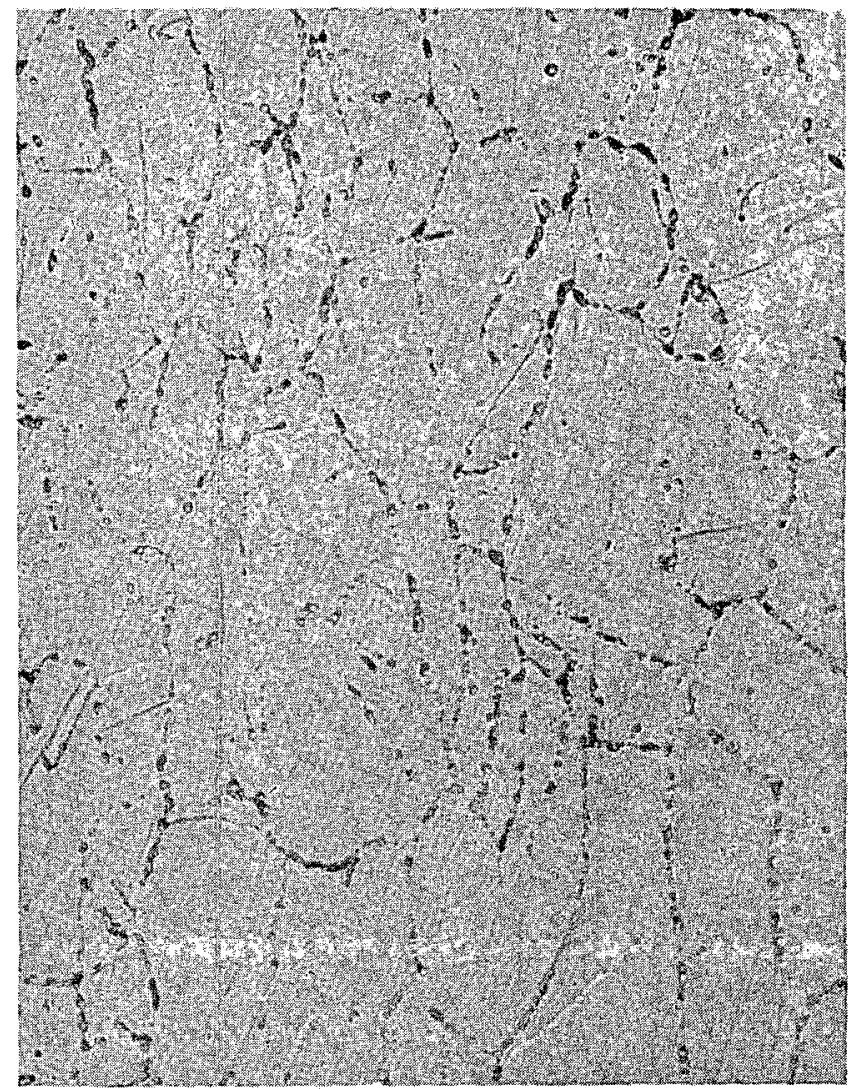

FIGURE 6. Typical High Energy

Rate Forged 21-6-9 Forging (500X)

boundaries of the worked grains is analogous to the higher temperature phase previously discussed. Precipitation along deformation bands was not evident in these samples, which were forged at higher temperatures. Deforming the alloy below $800^{\circ} \mathrm{C}$ and reheating at about $700^{\circ} \mathrm{C}$ causes heavy precipitation along deformation bands within the grains. Successive forging stages below $800{ }^{\circ} \mathrm{C}$ should be avoided in processing 21-6-9.

\section{Mechanical Properties}

Tensile properties were determined from the rolled wedge, deformed at $25^{\circ} \mathrm{C}$, at approximately 10,20 , 30 , and $40 \%$ deformation. Results from samples as-deformed and deformed plus stress-relieved for one hour at 480,590 , and $670^{\circ} \mathrm{C}$ are shown in Figures 7-11. Reduction in area (RA) was not significantly affected by either stress-relieving temperatures or amounts of deformation except 


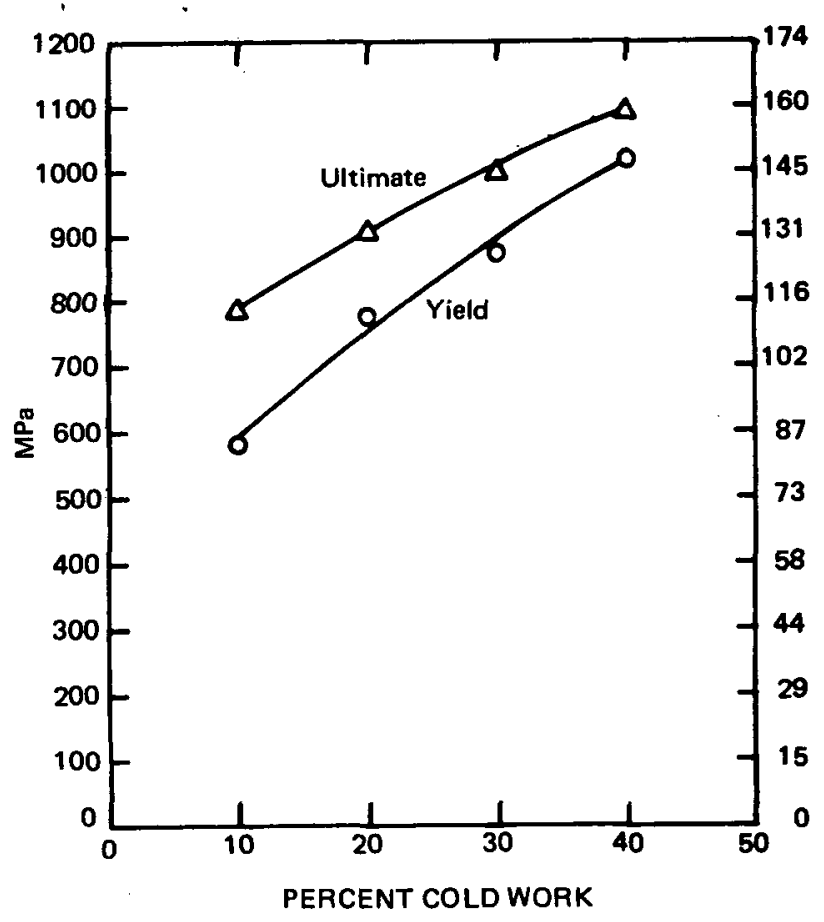

FIGURE 7. Yield and Ultimate Tensile Stresses of Thermomechanically Processed 21-6-9 as a Function of Percent Cold Work and No Stress Relieving

FIGURE 9. Same as Figure 7 but Stress Relieved One Hour at $590{ }^{\circ} \mathrm{C}$

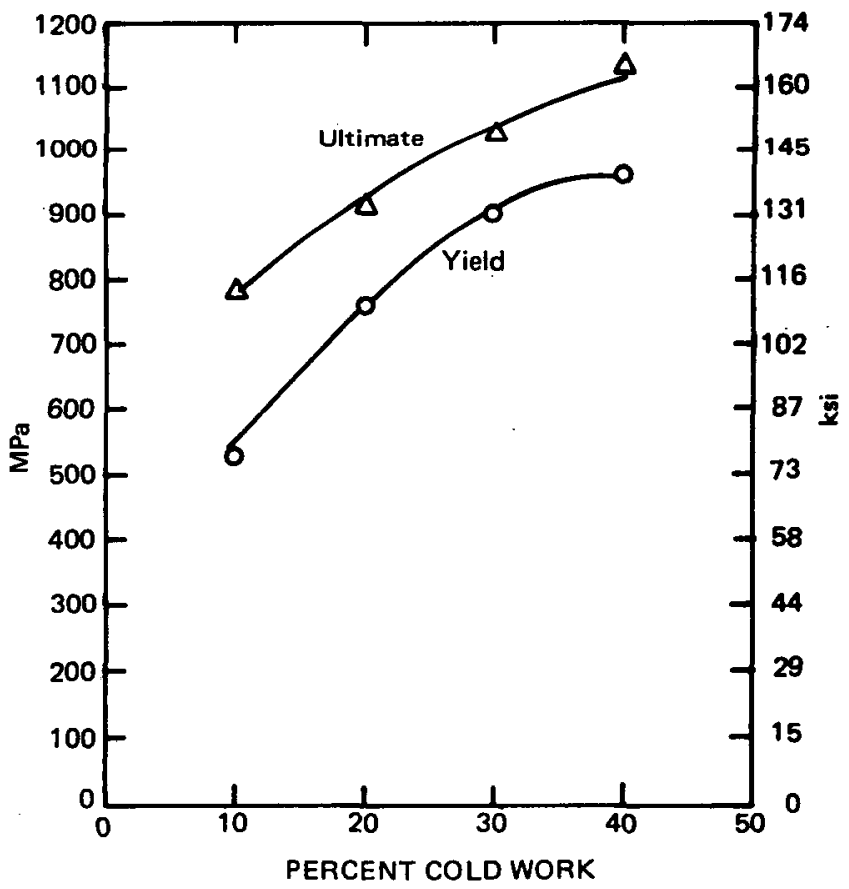

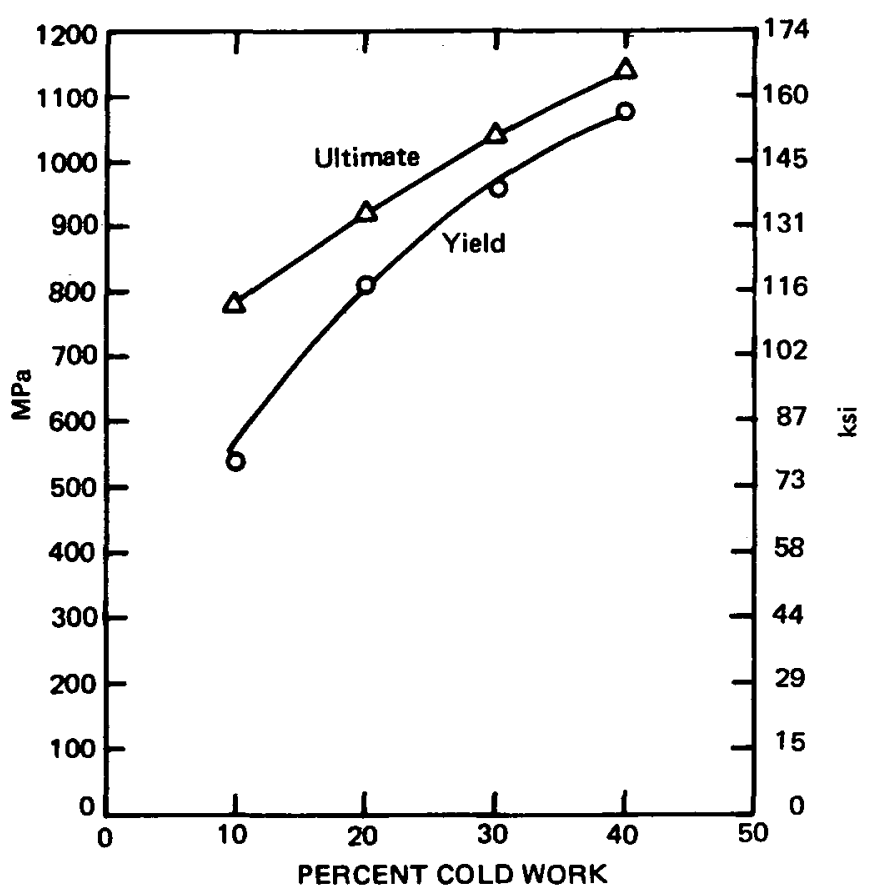

FIGURE 8. Same as Figure 7 but Stress Relieved One Hour at $480{ }^{\circ} \mathrm{C}$

FIGURE 10. Same as Figure 7 but Stress Relieved One Hour at $670{ }^{\circ} \mathrm{C}$

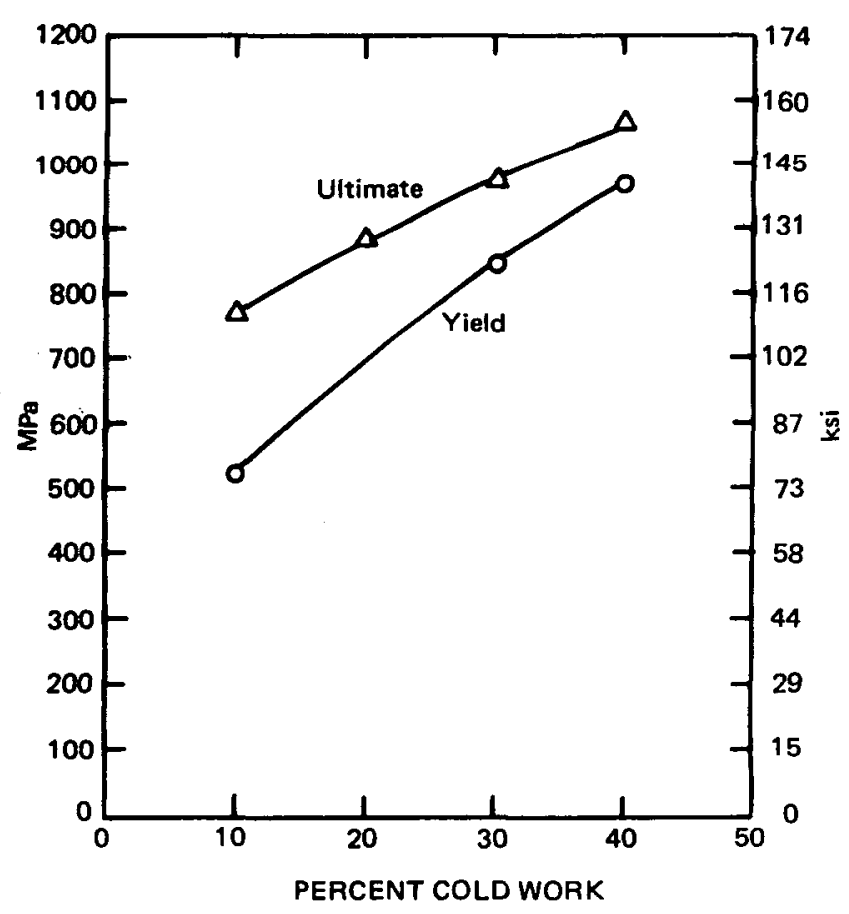


FIGURE 11. Ductilities for Thermomechanically Processed 21-6-9
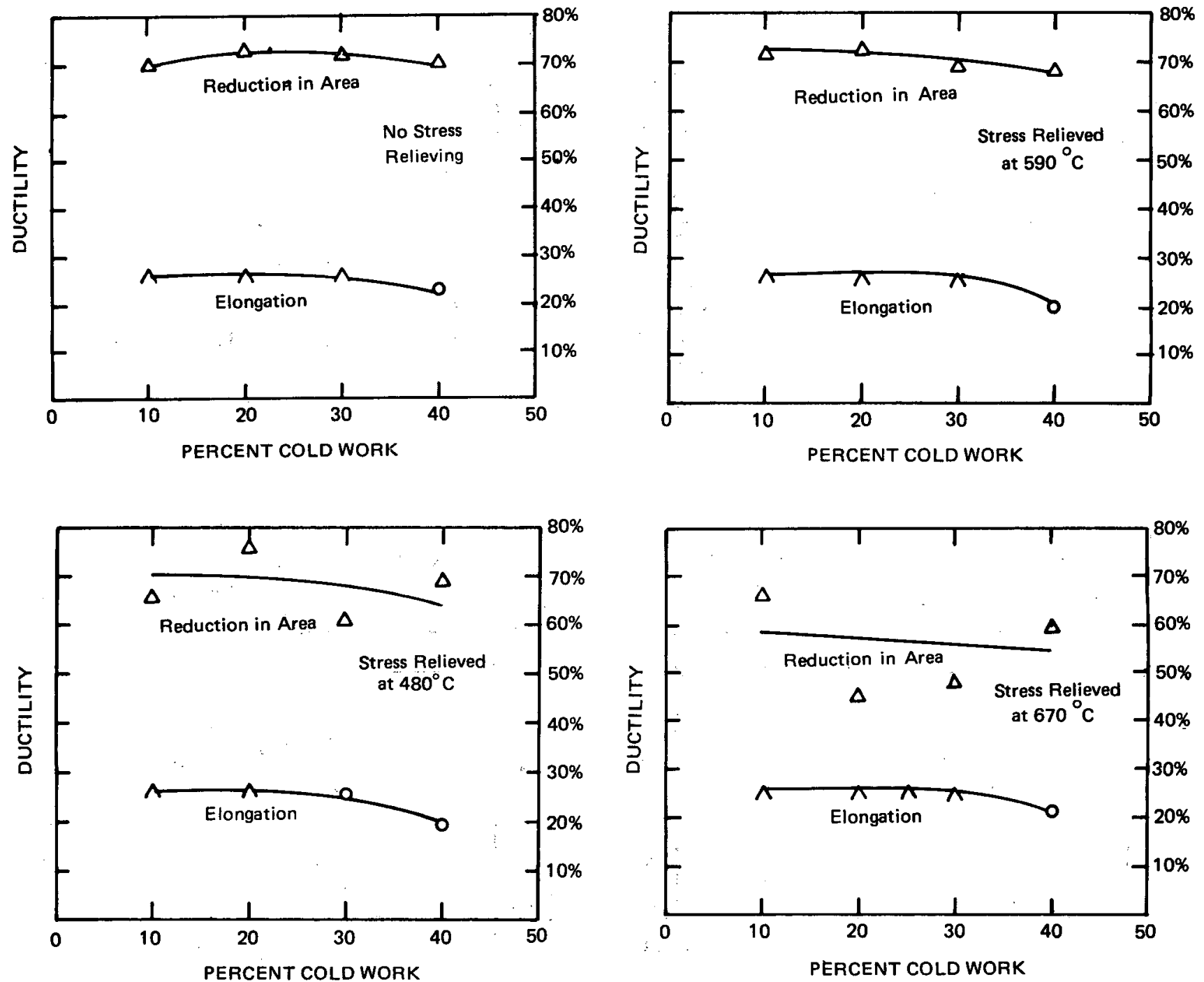

NOTE: $\wedge$ means "greater than" and represents data points that might have been higher. The equipment used, however, had limited measuring capabilities. 


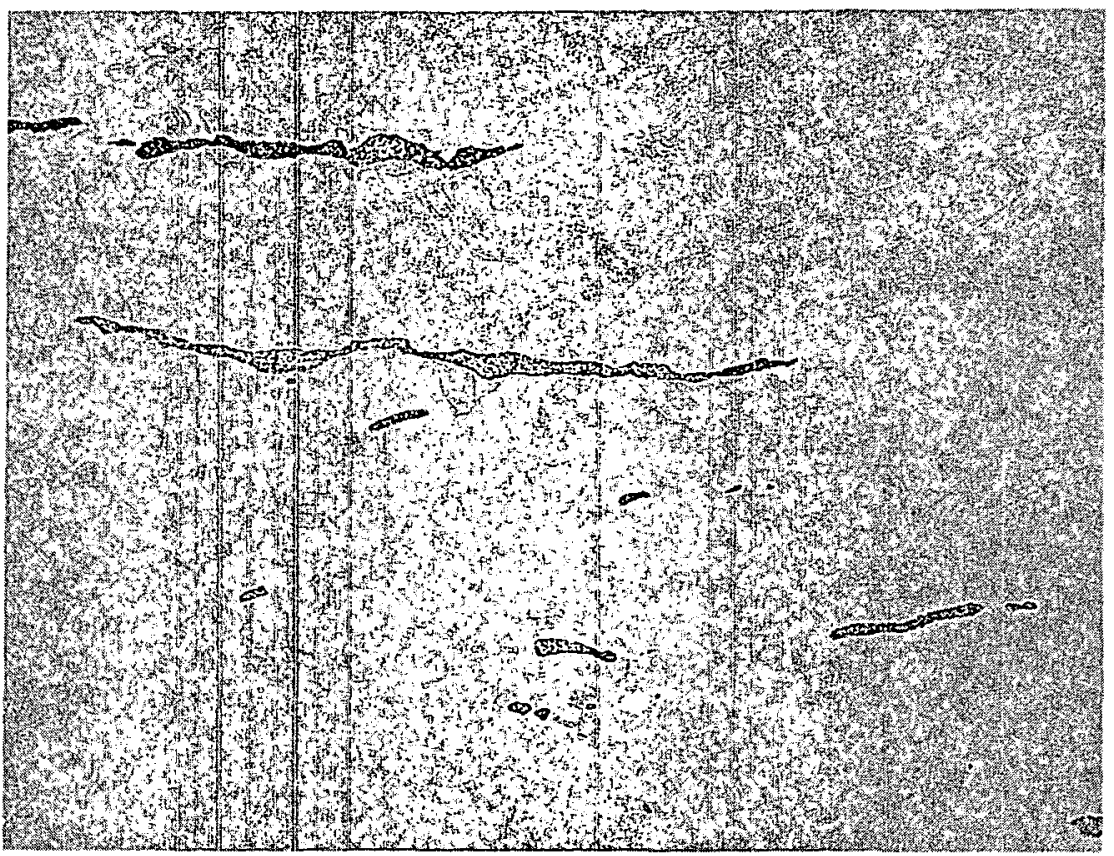

FIGURE 12. 21-6-9 Plate Showing

Ferrite Stringers (Kallings Etch, 200X)

at $670{ }^{\circ} \mathrm{C}$. Stress-relieving at $670{ }^{\circ} \mathrm{C}$, close to the sensitization range, caused a drop in RA. Total elongation was not significantly affected over the range investigated. Strength levels (Figures 7-10), however, increased dramatically with up to $40 \%$ cold work without an equivalent loss in ductility. There was a slight increase in strength and hardness values for the samples stress-relieved at 480 and $590{ }^{\circ} \mathrm{C}$.

Deformation twinning became very predominant at $20 \%$ deformation and above. Microstructures showed that grain boundary precipitation occurred only in the material stress-relieved at $670^{\circ} \mathrm{C}$; however, contrary to previous evidence, precipitation did not occur on the deformation bands. It was found that the initial stock used to machine the wedge contained numerous stringers as shown in Figure 12. The stringers were magnetic, and microprobe analysis showed that they were high in chromium and low in manganese as compared to the matrix. It is quite probable that the stringers are ferrite remaining in the alloy as a result of inadequate ingot breakdown. The presence of stringers also appeared to affect the precipitation behavior-possibly tying up carbon and/or nitrogen so that they are not as readily available to form precipitates along deformation bands and within grain boundaries. This experiment with the wedge is being repeated with homogeneous material to make certain that derived mechanical properties and precipitation behavior is not affected by the presence of the stringers.

\section{CONCLUSIONS}

From this study, it is evident that for TMP, a $1094{ }^{\circ} \mathrm{C}$ solutionizing treatment is necessary in 21-6-9 to completely dissolve prior precipitation. Also, warm-working the alloy in the range of 600 to $775^{\circ} \mathrm{C}$ or hot-working below the solution treatment temperature will result in heavy precipitation. Cold working the alloy below $500{ }^{\circ} \mathrm{C}$ is attractive for increasing strengths without forming an extensive network of precipitates.

Stress-relieving treatments should be held below $600{ }^{\circ} \mathrm{C}$. Rolling and forming schedules have been 
TABLE 3. Summary of Metallurgical

Reactions in 21-6-9 Stainless Steel

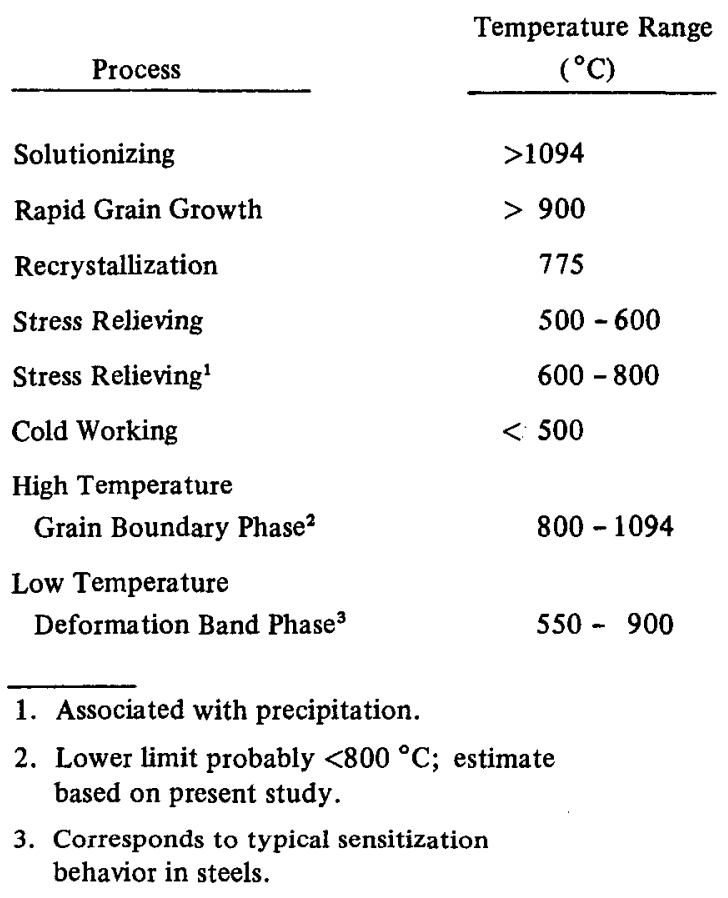

developed to produce high-strength 21-6-9 parts with good ductilities and with minimum precipitation of undesirable second phases. Such schedules also make use of the recrystallization mechanism that occurs around $775^{\circ} \mathrm{C}$ to produce a uniform fine-grained product.

The existence of at least two different types of precipitates, distinguished by either a different composition or a change in nucleation behavior, is an interesting result of this study.

Work is continuing toward obtaining a positive identification of the precipitates and to better understand the need for microstructural control during thermomechanical processing of 21-6-9. Initial results from this study show that to obtain a 21-6-9 product free of precipitation, it is necessary to either fully solutionize the alloy or deform the. alloy in the cold working range. High strengths can be achieved by cold working below $500^{\circ} \mathrm{C}$. A best estimate of important metallurgical reactions in 21-6-9 is compiled in Table 3. Estimates are based on what has been known about the alloy in addition to results from the present study. Further investigations are needed to better define temperature ranges.

\section{REFERENCES}

1. B. Weiss and R. Stickler. Met. Trans., Vol. 3, pp. 851-866. 1972 .

2. A. S. Grot and J. E. Spruiell. Met. Trans., Vol. 6A, pp. 2023-2030. 1975.

3. J. E. Spruiell, J. A. Scott, C. S. Ary, and R. L. Hardin. Met. Trans., Vol. 4, pp. 15331544. 1973.

4. Private communications with M. J. Carr, Phyșical Metallurgy Group, Rocky Flats Plant. 1977. 